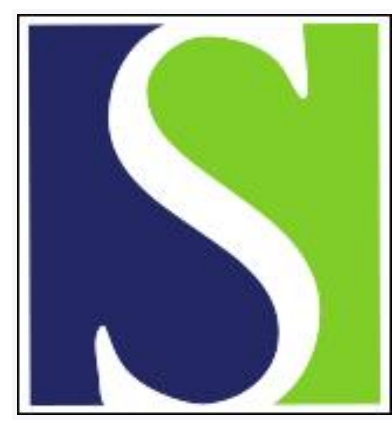

Scand J Work Environ Health 1995;21(6):419-426

https://doi.org/10.5271/sjweh.57

Issue date: Dec 1995

Mortality and cancer incidence among women with a high consumption of fatty fish contaminated with persistent organochlorine compounds

by Rylander L, Hagmar L

The following article refers to this text: 2004;30(1):30-35

Key terms: breast cancer; cancer incidence; cervical cancer; colon cancer; contamination; dichlorodiphenyltrichloroethane; fish; mortality; multiple myeloma; PCP; persistent organochlorine compound; polychlorinated biphenyl; polychlorinated dibenzo-p-dioxin; polychlorinated dibenzofuran; skin cancer; stomach cancer; woman

This article in PubMed: www.ncbi.nlm.nih.gov/pubmed/8824747 


\title{
Mortality and cancer incidence among women with a high consumption of fatty fish contaminated with persistent organochlorine compounds
}

\author{
by Lars Rylander, BSC, ${ }^{1}$ Lars Hagmar, $M D^{\prime}$
}

\begin{abstract}
Rylander L, Hagmar L. Mortality and cancer incidence among women with a high consumption of fatty fish contaminated with persistent organochlorine compounds. Scand J Work Environ Health 1995;21:419—26.
\end{abstract}

\begin{abstract}
Objectives The purpose of this study was to assess cancer incidence and cardiovascular mortality among women with a high dietary intake of fatty fish from the Baltic Sea (on the Swedish east coast), contaminated with persistent organochlorine compounds.

Material and methods Cohorts of fishermen's wives from the Swedish east (1989 subjects) and west (6605 subjects) coasts were established. The mortality and cancer incidence were studied in these cohorts, and comparisons were made with respective regional populations and between the cohorts. Dietary interviews were made with 200 randomly selected cohort women and equally many women from the general population. The interviewed east- and westcoast cohort women ate locally caught fatty fish at least twice as often as their referents.

Results Compared with that of the regional population, the breast cancer incidence was higher than expected in the eastcoast cohort [standardized incidence ratio (SIR) $1.29,95 \%$ confidence interval ( $95 \% \mathrm{CI}$ ) $0.96-1.71$ ], whereas it was lower in the westcoast cohort (SIR 0.89; 95\% CI 0.77-1.04). When a direct comparison was made between the two cohorts, the eastcoast women displayed an increased breast cancer incidence (incidence rate ratio $1.35,95 \% \mathrm{CI} 0.98-1.86$ ). No obvious difference was seen between the two cohorts concerning cardiovascular mortality.

Conclusions The results support, but do not prove, the hypothesis of an association between exposure to a mixture of persistent organochlorine compounds through fish consumption and an increased risk for breast cancer.
\end{abstract}

Key terms breast cancer, cervical cancer, colon cancer, dichlorodiphenyltrichloroethane, multiple myelomas, polychlorinated biphenyls, polychlorinated dibenzo-p-dioxins and furans, skin cancer, stomach cancer.

The consumption of fatty fish from the Baltic Sea, on the Swedish east coast, is the main exposure route for carcinogenic persistent organochlorine compounds, as for example polychlorinated biphenyls (PCB), polychlorinated dibenzo- $p$-dioxins (PCDD), polychlorinated dibenzofurans (PCDF), and dichlorodiphenyltrichloroethane (DDT), in the general Swedish population $(1,2)$. Cohorts of professional fishermen from different Swedish coastal areas have therefore been established to enable an assessment of whether a high dietary intake of fatty fish from the Baltic Sea may affect cancer incidence $(3,4)$. Thus far, the results indicate increased risks for stomach cancer, skin cancer, and multiple myelomas and a decreased risk for colon cancer among fishermen from the Swedish east coast (4). Whether this finding can be related to dietary habits is not known.

As animal experiments with 2,3,7,8-tetrachlorodibenzo-p-dioxin (TCDD) have shown gender-linked discrep- ancies in carcinogenic activity (5) and as accidental high exposures to PCB in the work environment have caused increased mortality from liver cancer among women, but not among men (6), the possible cancer effects from contaminated fatty fish should be evaluated also for women. In a cohort of female workers potentially exposed to dioxins at a chemical plant, nine cases of breast cancer were observed versus 4.2 expected (7). Moreover, breast cancer in women has, in some recent epidemiologic studies (8-11), but not in all $(12,13)$, been associated with an increased body burden of various persistent organochlorine compounds. The positive associations observed have been considered interesting, especially as some of these compounds, as $o, p$-DDT, methoxylated analogs of DDT, and certain PCB congeners have estrogenic effects $(14,15)$. On the other hand, TCDD and other persistent organochlorine compounds acting through the Ah receptor are antiestrogenic (14).

1 Department of Occupational and Environmental Medicine, University Hospital, Lund, Sweden.

Reprint requests to: Mr L Rylander, Department of Occupational and Environmental Medicine, University Hospital, S-221 85 Lund, Sweden. 
The direction of the endocrine effect from mixed exposure to persistent organochlorine compounds through a dietary intake of fatty fish is not known.

The main objective of the present study was to assess the cancer risk among women with a high dietary intake of fatty fish from the Baltic Sea. The wives of professional fishermen were considered a feasible study population. Studying the cancer incidence among these women without exposure to potential occupational confounding factors such as ultraviolet light, diesel exhaust, tars, and oils would also allow us to assess whether the observed cancer risk among male fishermen has been due to dietary or occupational factors (4). An additional objective was to assess whether a high fish intake, especially of fatty fish species rich in n-3 polyunsaturated fatty acids (PUFA), was associated with a decreased risk for ischemic heart disease (IHD), as indicated previously (16), and also observed among the male fishermen (4).

\section{Subjects and methods}

\section{Cohorts and follow-up}

Cohorts of fishermen from the Swedish east coast (Baltic Sea) and the west coast (Skagerrak and Kattegatt) have been established previously $(3,4)$. One inclusion criterion was that they should have been members of a fishermen's organization for at least one year. The eastcoast cohort was complete as from 1968, whereas the westcoast cohort was complete already from 1965 (4). The observation periods for mortality and cancer incidence started therefore in these calendar years.

By linkage to the national Swedish population register (SPAR) and to registers at the local parish offices, we identified 2175 women from the east coast and 7166 women from the west coast who were, or had been, married to these fishermen. A 10-digit personal identification code could, however, not be retrieved for seven women from the east coast and 104 women from the west coast, and they were therefore excluded. The date of entry into the cohorts was defined as the date of marriage or the date when their husbands had been fishermen for a year, whichever was the latest. One woman from the east coast and five women from the west coast were excluded as the date for their marriage could not be retrieved. Ninety-five women from the east coast and 109 from the west coast were excluded because they had died or been divorced from their husbands before the latter became fishermen. Moreover, 38 eastcoast women and 284 westcoast women were excluded because they had died or emigrated before the beginning of the observation period (1968 and 1965, respectively). Finally, 45 women from the east coast and 59 from the west coast were excluded since they had married a fisherman after
1989, which was the end of the present observation period. The county of living for three eastcoast women could not be established, and they were therefore excluded from the analyses using the regional general population for comparisons. The final eastcoast cohort comprised therefore 1986 women, and the corresponding figure for the westcoast cohort was 6605 . One of the westcoast cohort women had, however, been diagnosed with two cancers before the start of the observation period and was therefore included only in the analysis of mortality.

The start of follow-up was defined for each woman as the date of entry into the cohort or the start of the observation period, whichever was the latest. The median start of follow-up in the eastcoast cohort was 1969 (10th percentile 1968,90 th percentile 1986). The corresponding figure for the westcoast cohort was 1965 (10th percentile 1965 , 90th percentile 1979).

The women from the eastcoast cohort were younger (median year of birth 1936, 10th percentile 1910, 90th percentile 1956) than those from the west coast (median year of birth 1925,10 th percentile 1900,90 th percentile 1952).

Vital status was determined as of 31 December 1989 for all the subjects in the cohorts. Two hundred and thirty-seven women from the east coast and 1431 women from the west coast had died, four and three, respectively, had emigrated, and none was lost to follow-up.

Date of death or emigration was used as the individual end points for mortality, whichever occurred first. Similarly, date of death, diagnosis of a second tumor (irrespective of site), or emigration was used as the individual end points for cancer incidence, whichever occurred first.

\section{Information on causes of death and tumors}

Information on cause of death for the period 1968-1989 for the eastcoast cohort and 1965-1989 for the westcoast cohort was obtained from Statistics Sweden. The death certificates were coded according to the International Classification of Diseases (ICD). All of the codes were transformed to the 8 th revision of the ICD.

Information on tumors (coded according to the ICD, 7th revision), diagnosed from 1968 to 1989 in the eastcoast cohort, and from 1965 to 1989 in the westcoast cohort, was obtained from the Swedish Cancer Registry.

\section{Expected numbers}

Expected mortality for the periods 1968-1989 and 1965 - 1989 was determined for each county from death rates specific for cause, gender, calendar year, and fiveyear age groups. These rates were calculated from death and population counts obtained from Statistics Sweden. Similarly, yearly incidence rates for specific malignant 
Table 1. Food frequencies of the randomly selected cohort of women from the east and west coasts and their referents, matched by age, gender, and county.

\begin{tabular}{|c|c|c|c|c|c|c|c|c|}
\hline \multirow[t]{3}{*}{ Type of consumption } & \multicolumn{4}{|c|}{ Cohort women } & \multicolumn{4}{|c|}{ Referents } \\
\hline & \multicolumn{2}{|c|}{$\begin{array}{l}\text { East coast } \\
(N=100)\end{array}$} & \multicolumn{2}{|c|}{$\begin{array}{l}\text { West coast } \\
(N=100)\end{array}$} & \multicolumn{2}{|c|}{$\begin{array}{l}\text { East coast } \\
(N=100)\end{array}$} & \multicolumn{2}{|c|}{$\begin{array}{l}\text { West coast } \\
(N=100)\end{array}$} \\
\hline & Mean & SD & Mean & SD & Mean & SD & Mean & SD \\
\hline \multicolumn{9}{|l|}{ Locally caught fish (meals per month) } \\
\hline $\begin{array}{l}\text { Lean fish } \\
\text { Fatty fish } \\
\text { Total }\end{array}$ & $\begin{array}{l}4.5 \\
3.6 \\
8.1\end{array}$ & $\begin{array}{l}4.0 \\
3.6 \\
6.2\end{array}$ & $\begin{array}{r}7.2 \\
3.5 \\
10.6\end{array}$ & $\begin{array}{l}4.0 \\
4.6 \\
6.5\end{array}$ & $\begin{array}{l}1.8 \\
1.8 \\
3.6\end{array}$ & $\begin{array}{l}2.8 \\
2.1 \\
4.1\end{array}$ & $\begin{array}{l}3.1 \\
1.5 \\
4.6\end{array}$ & $\begin{array}{l}3.0 \\
2.1 \\
4.0\end{array}$ \\
\hline \multicolumn{9}{|l|}{ Not locally caught fish (meals per month) } \\
\hline $\begin{array}{l}\text { Lean fish } \\
\text { Fatty fish } \\
\text { Unspecified } \\
\text { Total }\end{array}$ & $\begin{array}{l}0.5 \\
0.2 \\
0.2 \\
0.8\end{array}$ & $\begin{array}{l}1.2 \\
0.4 \\
0.7 \\
1.7\end{array}$ & $\begin{array}{l}0.7 \\
0.5 \\
0.5 \\
1.7\end{array}$ & $\begin{array}{l}1.7 \\
1.2 \\
1.0 \\
2.6\end{array}$ & $\begin{array}{l}1.7 \\
0.9 \\
0.6 \\
3.2\end{array}$ & $\begin{array}{l}1.8 \\
1.5 \\
1.1 \\
3.0\end{array}$ & $\begin{array}{l}1.5 \\
0.9 \\
0.7 \\
3.1\end{array}$ & $\begin{array}{l}1.9 \\
1.2 \\
1.2 \\
2.9\end{array}$ \\
\hline $\begin{array}{l}\text { Smoked fish (meals per month) } \\
\text { Shellfish (meals per month) } \\
\text { Meat (meals per month) } \\
\text { Chicken (meals per month) } \\
\text { Sausages, bacon (meals per month) } \\
\text { Fresh vegetables (monthly) } \\
\text { Fresh fruits (number per month) } \\
\text { Coffee (cups per day) } \\
\text { Alcohol (gram alcohol per month) }\end{array}$ & $\begin{array}{c}0.7 \\
1.0 \\
8.9 \\
2.0 \\
3.9 \\
21 \\
39 \\
4.3 \\
87\end{array}$ & $\begin{array}{c}1.1 \\
1.7 \\
5.3 \\
1.8 \\
2.9 \\
10 \\
25 \\
3.0 \\
110\end{array}$ & $\begin{array}{l}0.3 \\
2.3 \\
9.0 \\
1.2 \\
3.4 \\
23 \\
45 \\
3.6 \\
70\end{array}$ & $\begin{array}{c}0.6 \\
2.0 \\
4.7 \\
1.2 \\
2.6 \\
10 \\
38 \\
2.0 \\
116\end{array}$ & $\begin{array}{c}0.4 \\
1.1 \\
9.8 \\
1.8 \\
3.7 \\
21 \\
46 \\
3.6 \\
132\end{array}$ & $\begin{array}{r}0.7 \\
1.1 \\
4.9 \\
1.4 \\
2.9 \\
11 \\
30 \\
2.0 \\
166\end{array}$ & $\begin{array}{c}0.5 \\
1.6 \\
11 \\
2.2 \\
3.4 \\
21 \\
48 \\
3.4 \\
124\end{array}$ & $\begin{array}{r}1.0 \\
1.8 \\
6.2 \\
2.0 \\
3.2 \\
11 \\
31 \\
2.4 \\
147\end{array}$ \\
\hline
\end{tabular}

tumors were obtained from the Swedish Cancer Registry.

\section{Dietary interviews}

Dietary interviews were performed with a random sample of 100 east- and 100 westcoast cohort women, and with equally many randomly selected reference women from the general population, matched with respect to age and county of living. Of the original samples, 31 eastand 40 westcoast cohort women, and 81 reference women refused to participate in the dietary interviews. New subjects were therefore selected at random. The questionnaires were distributed to the interviewed women beforehand, together with color pictures of three different sizes of fish portions. The food frequencies for several different food items, as well as coffee, tobacco, and alcohol consumption, were assessed, together with the average amount of consumed fish (tables 1-3). The women were also asked about their food frequencies today compared with $10-20$ years ago.

\section{Fish consumption}

The interviewed women from both the east- and the westcoast cohorts ate locally caught fish more than twice as often as compared with their referents (table 1). The westcoast cohort ate fish more often than the eastcoast cohort, but this discrepancy was totally due to a different consumption of lean fish. The eastcoast cohort had, on the other hand, a slightly higher intake of fatty fish (table 3 ). The older women from both the east- and the westcoast cohorts ate locally caught fish more frequently than the younger women (table 4 ). The consumption of locally caught fish had decreased during the last $10-20$ years, but no difference was seen in that respect between the studied groups (data not shown).

The women from the eastcoast cohort ate smoked fish almost twice as often as both their referents and women from the westcoast cohort (table 1). On the other hand, the westcoast cohort women had a higher intake of shellfish.

\section{Other dietary habits and coffee, alcohol and tobacco consumption}

Data from the interviews indicated that the eastcoast cohort had a slightly higher coffee consumption than its referents and the westcoast cohort (table 1). The westcoast cohort ate chicken less frequently than both its referents and the eastcoast cohort. The referents from the west coast ate meat more often than the women on the west coast. Women from both cohorts reported a lower alcohol consumption than their referents. There was a somewhat higher proportion of smoking among women

Table 2. Smoking habits of the randomly selected cohort women from the east and west coasts and their referents, matched by age, gender, and county.

\begin{tabular}{|c|c|c|c|c|}
\hline \multirow[t]{2}{*}{ Smoking status } & \multicolumn{2}{|c|}{ Cohort women } & \multicolumn{2}{|c|}{ Referents } \\
\hline & $\begin{array}{c}\text { East coast } \\
(\mathbb{N}=100) \\
(N)\end{array}$ & $\begin{array}{c}\text { West coast } \\
(N=100) \\
(N)\end{array}$ & $\begin{array}{c}\text { East coast } \\
(N=100) \\
(N)\end{array}$ & $\begin{array}{c}\text { West coast } \\
(N=100) \\
(N)\end{array}$ \\
\hline Nonsmokers & 55 & 64 & 52 & 62 \\
\hline Ex-smokers & 16 & 17 & 27 & 22 \\
\hline Current smokers & 29 & 19 & 21 & 16 \\
\hline
\end{tabular}


Table 3. Consumption of species of locally caught fatty fish for the cohort from the east and west coasts and their referents, matched by age, gender, and county.

\begin{tabular}{|c|c|c|c|c|c|c|c|c|}
\hline \multirow[t]{3}{*}{ Locally caught fatty fish (kg per month) } & \multicolumn{4}{|c|}{ Cohort women } & \multicolumn{4}{|c|}{ Referents } \\
\hline & \multicolumn{2}{|c|}{$\begin{array}{l}\text { East coast } \\
(\mathbb{N}=100)\end{array}$} & \multicolumn{2}{|c|}{$\begin{array}{l}\text { West coast } \\
(N=100)\end{array}$} & \multicolumn{2}{|c|}{$\begin{array}{l}\text { East coast } \\
(N=100)\end{array}$} & \multicolumn{2}{|c|}{$\begin{array}{l}\text { West coast } \\
(N=100)\end{array}$} \\
\hline & Mean & $\mathrm{SD}$ & Mean & SD & Mean & SD & Mean & SD \\
\hline $\begin{array}{l}\text { Salmon } \\
\text { Herring }\end{array}$ & $\begin{array}{l}0.34 \\
0.56\end{array}$ & $\begin{array}{l}0.47 \\
0.69\end{array}$ & $\begin{array}{l}0.46 \\
0.31\end{array}$ & $\begin{array}{l}0.65 \\
0.66\end{array}$ & $\begin{array}{l}0.16 \\
0.25\end{array}$ & $\begin{array}{l}0.34 \\
0.40\end{array}$ & $\begin{array}{l}0.15 \\
0.15\end{array}$ & $\begin{array}{l}0.23 \\
0.30\end{array}$ \\
\hline Total & 0.90 & 1.01 & 0.76 & 1.13 & 0.41 & 0.57 & 0.30 & 0.39 \\
\hline
\end{tabular}

Table 4. Food frequencies of locally caught fish for 100 cohort women from the east and west coasts divided into three categories with respect to year of birth.

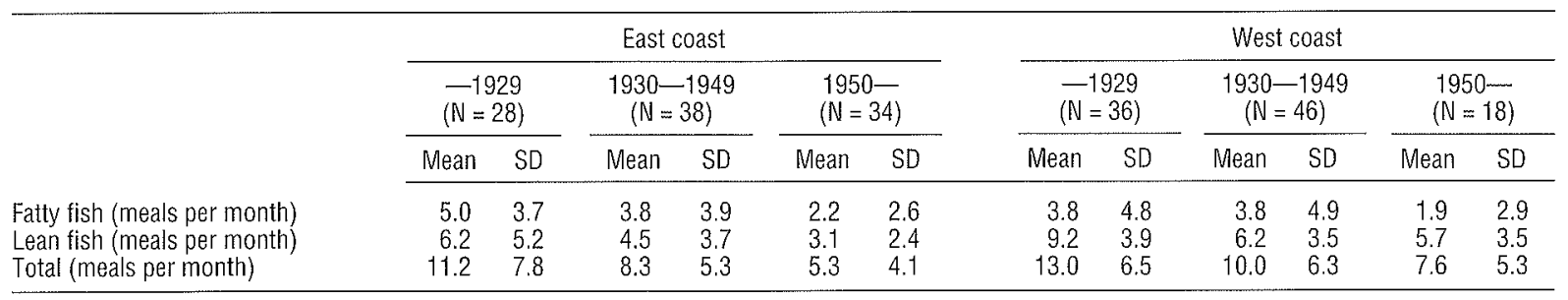

in the eastcoast cohort (table 2). No differences in the consumption of fresh fruits and vegetables were seen between the groups. The consumption of fresh fruits and vegetables had increased during the last $10-20$ years, but there was no difference between the studied groups (data not shown).

\section{Statistical methods}

Exact $95 \%$ confidence intervals $(95 \% \mathrm{CI}$ ) for causespecific standardized mortality ratios (SMR) or standardized cancer incidence ratio (SIR) were calculated by treating the observed number as a Poisson variable. However, if the observed number was greater than 15, approximate confidence limits were computed (17). Testing for trends in the standardized incidence ratio was performed according to Breslow \& Day (18). Direct comparisons of mortality (mortality rate ratio, MRR) and cancer incidence (incidence rate ratio, IRR) between the east- and westcoast cohorts were performed by means of a Poisson regression (19), for appropriate age ( $\geq 39$, $40-49,50-59,60-69$, and $\leq 70$ years) and calendar year (1972 or before, 1973-1978, 1979-1983, and 1984-1989) strata, using EGRET software (Statistics and Epidemiology Research Corporation, Seattle).

\section{Results}

\section{Mortality}

The overall mortality did not differ from the expected figure in any of the cohorts (table 5). An increased mor- tality from malignant neoplasms (SIR 1.23, 95\% CI $0.98-1.52$ ) was, however, observed in the eastcoast cohort. This increased mortality was mainly due to increased mortality from breast cancer (SIR $1.74,95 \% \mathrm{CI}$ $1.08-2.72$ ). For mortality from ischemic heart diseases in the eastcoast cohort, compared with the background population, the confidence interval did not support any difference, whereas a decreased incidence was seen for the westcoast cohort (SIR 0.92, 95\% CI 0.83-1.01). In both cohorts, deaths due to accidents, poisonings or violence were fewer than expected, mainly due to fewer suicides.

\section{Cancer incidence}

The overall cancer incidence was increased (SIR 1.17, 95\% CI 1.00-1.36) in the eastcoast cohort (table 6), whereas it was decreased in the westcoast cohort (SIR $0.94,95 \% \mathrm{CI} 0.87-1.01$ ). The breast cancer incidence was higher than expected in the eastcoast cohort (SIR $1.29,95 \%$ CI $0.96-1.71$ ), whereas it was lower in the westcoast cohort (SIR $0.89,95 \%$ CI $0.77-1.04$ ), although the confidence intervals did not imply firm support. For cervical cancer, a similar difference was found. Whereas the incidence of corpus cancer was as expected in the westcoast cohort, it was slightly enhanced in the eastcoast cohort. The interpretation of these data was, however, hampered by the wide confidence intervals. The risk for ovarian cancer seemed to be low in both cohorts.

The risk for colon cancer did not substantially differ from unity in either the east- or westcoast cohort. There were no indications of increased risks for skin or stomach 
Table 5. Mortality by detailed cause in 1968-1989 among 1986 women from the eastcoast cohort and in 1965-1989 among 6605 from the westcoast cohort. $(0=$ observed number of deaths, $E=$ expected number of deaths, $S M R=$ standardized mortality ratio, $95 \% \mathrm{Cl}=95 \%$ confidence interval)

\begin{tabular}{|c|c|c|c|c|c|c|c|c|}
\hline \multirow[t]{2}{*}{ Cause of death ${ }^{a}$} & \multicolumn{4}{|c|}{ East coast } & \multicolumn{4}{|c|}{ West coast } \\
\hline & 0 & $E$ & SMR & $95 \% \mathrm{Cl}$ & 0 & $\mathrm{E}$ & SMR & $95 \% \mathrm{Cl}$ \\
\hline All causes $(000-999)$ & 237 & 228 & 1.04 & $0.91-1.18$ & 1431 & 1468 & 0.97 & $0.93-1.03$ \\
\hline All malignant neoplasms (140-209) & 84 & 68 & 1.23 & $0.98--1.52$ & 374 & 390 & 0.96 & $0.87-1.06$ \\
\hline $\begin{array}{l}\text { Breast (174) } \\
\text { Multiple myeloma (203) } \\
\text { Leukemia (204-207) }\end{array}$ & $\begin{array}{r}20 \\
1 \\
3\end{array}$ & $\begin{array}{r}11 \\
1.5 \\
2.3\end{array}$ & $\begin{array}{l}1.74 \\
0.65 \\
1.33\end{array}$ & $\begin{array}{l}1.08-2.72 \\
0.02-3.62 \\
0.27-3.88\end{array}$ & $\begin{array}{l}61 \\
13 \\
10\end{array}$ & $\begin{array}{c}67 \\
7.3 \\
12\end{array}$ & $\begin{array}{l}0.91 \\
1.77 \\
0.85\end{array}$ & $\begin{array}{l}0.70-1.17 \\
0.94-3.03 \\
0.41-1.56\end{array}$ \\
\hline Cardiovascular diseases (390-458) & 110 & 109 & 1.01 & $0.83-1.22$ & 783 & 805 & 0.97 & $0.91-1.04$ \\
\hline $\begin{array}{l}\text { Ischemic heart diseases }(410-414) \\
\text { Cerebrovascular diseases }(430-438)\end{array}$ & $\begin{array}{l}68 \\
22\end{array}$ & $\begin{array}{l}62 \\
26\end{array}$ & $\begin{array}{l}1.10 \\
0.85\end{array}$ & $\begin{array}{l}0.86-1.40 \\
0.54-1.30\end{array}$ & $\begin{array}{l}410 \\
211\end{array}$ & $\begin{array}{l}446 \\
198\end{array}$ & $\begin{array}{l}0.92 \\
1.07\end{array}$ & $\begin{array}{l}0.83-1.01 \\
0.93-1.22\end{array}$ \\
\hline Bronchitis, emphysema (490-493) & 2 & 3.5 & 0.57 & $0.07-2.08$ & 16 & 22 & 0.73 & $0.43-1.20$ \\
\hline Accidents, poisoning, violence (800-999) & 6 & 12 & 0.51 & $0.19-1.10$ & 43 & 66 & 0.65 & $0.48-0.88$ \\
\hline Suicide $(950-959)$ & - & 4.5 & 0.00 & $0.00-0.81$ & 5 & 17 & 0.30 & $0.10-0.70$ \\
\hline Alcohol-related deaths $(291,303,571,577,860)$ & 4 & 2.9 & 1.40 & $0.38-3.58$ & 12 & 13 & 0.96 & $0.50-1.68$ \\
\hline
\end{tabular}

a Code of the International Classification of Diseases (eighth revision) in parentheses.

Table 6. Cancer incidence in 1968-1989 among 1986 women from the eastcoast cohort and in 1965-1989 among 6604 from the westcoast cohort. $(0=$ observed number, $\mathrm{E}=$ expected number, $\mathrm{SIR}=$ standardized incidence ratio, $95 \% \mathrm{Cl}=95 \%$ confidence interval)

\begin{tabular}{|c|c|c|c|c|c|c|c|c|}
\hline \multirow[t]{2}{*}{ Cancer site ${ }^{a}$} & \multicolumn{4}{|c|}{ East coast } & \multicolumn{4}{|c|}{ West coast } \\
\hline & 0 & $E$ & SIR & $95 \% \mathrm{Cl}$ & 0 & $E$ & SIR & $95 \% \mathrm{Cl}$ \\
\hline All $(140-209)$ & 169 & 144 & 1.17 & $1.00-1.36$ & 696 & 740 & 0.94 & $0.87-1.01$ \\
\hline Lips (140) & - & 0.3 & 0.00 & $0.00-13.7$ & 1 & 1.8 & 0.57 & $0.01-3.18$ \\
\hline Stomach (151) & 5 & 5.4 & 0.93 & $0.30-2.16$ & 30 & 31 & 0.96 & $0.65-1.38$ \\
\hline Colon (153) & 15 & 11 & 1.36 & $0.76-2.24$ & 53 & 61 & 0.87 & $0.65-1.14$ \\
\hline Rectum (154) & 6 & 5.3 & 1.14 & $0.42-2.47$ & 27 & 28 & 0.96 & $0.64-1.41$ \\
\hline Liver, bile ducts (155) & 6 & 4.5 & 1.34 & $0.49-2.92$ & 32 & 24 & 1.32 & $0.92-1.89$ \\
\hline Lung (162.0-162.1) & 5 & 4.6 & 1.09 & $0.36-2.55$ & 15 & 22 & 0.68 & $0.38-1.12$ \\
\hline Breast $(170)$ & 49 & 38 & 1.29 & $0.96-1.71$ & 171 & 192 & 0.89 & $0.77-1.04$ \\
\hline Cervix uteri $(171)$ & 8 & 5.4 & 1.49 & $0.64-2.93$ & 18 & 25 & 0.73 & $0.44-1.16$ \\
\hline Corpus uteri $(172,174)$ & 12 & 8.8 & 1.37 & $0.71-2.40$ & 49 & 48 & 1.03 & $0.77-1.37$ \\
\hline Ovary (175) & 6 & 9.6 & 0.63 & $0.23-1.36$ & 44 & 52 & 0.85 & $0.62-1.14$ \\
\hline Melanoma (190) & 3 & 4.2 & 0.71 & $0.15-2.07$ & 25 & 24 & 1.05 & $0.69-1.57$ \\
\hline Skin (191) & 1 & 3.9 & 0.26 & $0.01-1.44$ & 14 & 19 & 0.74 & $0.40-1.24$ \\
\hline Brain (193) & 7 & 5.4 & 1.31 & $0.53-2.69$ & 26 & 23 & 1.13 & $0.75-1.68$ \\
\hline Soft-tissue sarcoma (197) & 1 & 1.0 & 1.00 & $0.03-5.57$ & 3 & 4.7 & 0.64 & $0.13-1.87$ \\
\hline Lymphohematopoietic $(200-207)$ & 9 & 8.4 & 1.07 & $0.49-2.04$ & 52 & 39 & 1.32 & $0.99-1.74$ \\
\hline Multiple myeloma (203) & 2 & 1.8 & 1.13 & $0.14-4.08$ & 15 & 9.3 & 1.61 & $0.90-2.66$ \\
\hline
\end{tabular}

a Code of the International Classification of Diseases (seventh revision) in parentheses.

cancer in any of the cohorts. However only a few stomach cancers and, for example, multiple myelomas were expected in the eastcoast cohort during the observation period, and therefore a precise evaluation is impossible at this time. In the westcoast cohort an increased risk was observed for multiple myeloma (SIR 1.61, 95\% CI $0.90-2.66$ ).

\section{Direct comparisons between the cohorts}

A direct comparison between the two cohorts did not reveal any difference in either overall mortality or cardiovascular diseases (table 7). The overall cancer risk was higher in the eastcoast cohort (IRR 1.19, 95\% CI 1.001.41). The eastcoast cohort had an increased breast can- cer incidence (IRR $1.35,95 \%$ CI $0.98-1.86$ ); the confidence intervals were wider for the observed risk increases in cervical and corpus cancer.

\section{Breast cancer incidence with respect to age and calendar year at diagnosis}

When comparisons were made with the general population, the point estimate for breast cancer risk in the eastcoast cohort was somewhat higher during the first part of the observation period (1968-1978), but no difference in risk could, however, be established for calendar year (test for trend, $\mathrm{P}=0.3$ ) (table 8). A direct comparison between the two cohorts showed a $70 \%$ increased incidence for the eastcoast cohort during the first part of the 
observation period, and a $16 \%$ increase during the latter part. This difference was, however, not significant (test for interaction in the Poisson regression model, $\mathrm{P}=0.3$ ). In the eastcoast cohort the age at diagnosis $(<50$ years versus $\geq 50$ years) did not affect the breast cancer risk, whereas a slight difference was seen in the westcoast cohort (test for trends, $\mathrm{P}=0.051$ ), when comparisons were made with the general population.

\section{Discussion}

The main result of the present study was the increased breast cancer incidence among the fishermen's wives from the east coast, as compared with the westcoast wives.

The relatively limited number of women interviewed $(\mathrm{N}=400$ ) might have somewhat decreased the precision in evaluating minor differences in dietary habits between the groups. A substantial proportion of the subjects randomly selected for dietary interviews refused to participate, and new subjects had to be selected. However, the

Table 7. Direct comparisons of mortality (MRR) and cancer incidence (IRR) between the east- and westcoast cohort, calculated by Poisson regression using data stratified for age and calendar time. $(95 \% \mathrm{Cl}=95 \%$ confidence interval)

\begin{tabular}{lcc}
\hline $\begin{array}{l}\text { Cause of death/ } \\
\text { cancer site }\end{array}$ & $\begin{array}{c}\text { MRR/ } \\
\text { IRR }\end{array}$ & $95 \% \mathrm{Cl}$ \\
\hline $\begin{array}{l}\text { Mortality } \\
\text { All causes (000-999) }\end{array}$ & 1.00 & $0.87-1.15$ \\
All malignant neoplasms (140-209) & 1.18 & $0.93-1.50$ \\
$\quad$ Breast (174) & 1.68 & $1.01-2.80$ \\
Cardiovascular diseases (390-458) & 0.92 & $0.75-1.13$ \\
$\quad$ Ischemic heart diseases (410-414) & 1.09 & $0.84-1.41$ \\
Cancer incidence & & \\
All (140-209) & 1.19 & $1.00-1.41$ \\
Breast (170) & 1.35 & $0.98-1.86$ \\
Cervix uteri (171) & 1.93 & $0.83-4.50$ \\
Corpus uteri (172, 174) & 1.16 & $0.61-2.20$ \\
\hline a Code of the international Classification of Diseases (eighth revision for \\
$\quad$ mortality and seventh revision for incidence) in parentheses.
\end{tabular}

proportion of refusers was similar for the fishermen's wives and the women from the general population. Moreover, the procedure of selecting new subjects for interview did not affect the age distribution as compared with the original sample. The high proportion of refusers may only have affected the validity of the dietary comparisons if the differences in habits between the refusers and nonrefusers differed between the studied groups.

Women who have never been married carry a somewhat higher risk for breast cancer (20). Both the eastand westcoast cohorts exclusively comprised married or previously married women; therefore an underestimation of breast cancer risk may have occurred in comparison with that of the general population. High socioeconomic status, urban living, obesity, age at first full-term pregnancy, parity, and height are also established risk factors for breast cancer. A previous analysis of the reproductive outcome of the women in the two cohorts showed, however, no cohort differences with respect to these potential confounders (21). Moreover, excessive alcohol consumption may also be a risk factor for breast cancer, but the alcohol consumption pattern did not differ between the cohorts.

Our results may offer some support to the hypothesis of an association between exposure to a mixture of persistent organochlorine compounds and an increased risk for breast cancer ( $8-11$ ), but firm evidence is still lacking. Neither was an association proved between a high intake of fatty fish from the Baltic Sea and breast cancer.

One weakness of our study design was the lack of measurements of, for example, PCB, PCDD and PCDF in blood. Similar discrepancies in fish consumption patterns as in our study were, however, seen between the east- and westcoast fishermen and their referents, and the blood levels of dioxin-like organochlorine compounds, expressed as toxic equivalents (TEQ), were at least two times higher for the eastcoast fishermen than for both their referents from the general population and the westcoast fishermen (22).

In a recent study, the plasma levels of 2,2-bis(4chlorophenyl)-1,1- dichloroethylene (DDE) and PCB 99 (IUPAC) were increased only in women with estrogen

Table 8. Breast cancer incidence in the east- and westcoast cohorts for the periods 1965(68) - 1978 and 1979 - 1989, with respect to age at diagnosis. A direct comparison between the cohorts (IRR = incidence rate ratio) is also included. $(0=$ observed number of cases, $\mathrm{SIR}=$ standardized incidence ratio, $95 \% \mathrm{Cl}=95 \%$ confidence interval)

\begin{tabular}{|c|c|c|c|c|c|c|c|c|}
\hline \multirow[t]{2}{*}{ Time period } & \multicolumn{3}{|c|}{ East coast } & \multicolumn{3}{|c|}{ West coast } & \multicolumn{2}{|c|}{ East coast versus west coast } \\
\hline & 0 & SIR & $95 \% \mathrm{Cl}$ & 0 & $\mathrm{SIR}$ & $95 \% \mathrm{Cl}$ & IRR & $95 \% \mathrm{Cl}$ \\
\hline $1965(68)-1978$ & 21 & 1.56 & $0.98-2.42$ & 77 & 0.85 & $0.68-1.07$ & 1.70 & $1.04-2.77$ \\
\hline $\begin{array}{l}<50 \text { years of age } \\
\geq 50 \text { years of age }\end{array}$ & $\begin{array}{r}5 \\
16\end{array}$ & $\begin{array}{l}1.41 \\
1.62\end{array}$ & $\begin{array}{l}0.46-3.29 \\
0.95-2.67\end{array}$ & $\begin{array}{l}13 \\
64\end{array}$ & $\begin{array}{l}0.65 \\
0.91\end{array}$ & $\begin{array}{l}0.34-1.11 \\
0.71-1.17\end{array}$ & $\begin{array}{l}1.84 \\
1.66\end{array}$ & $\begin{array}{l}0.65-5.19 \\
0.95-2.89\end{array}$ \\
\hline $1979-1989$ & 28 & 1.13 & $0.76-1.66$ & 94 & 0.93 & $0.75-1.14$ & 1.16 & $0.76-1.78$ \\
\hline $\begin{array}{l}<50 \text { years of age } \\
\geq 50 \text { years of age }\end{array}$ & $\begin{array}{r}4 \\
24\end{array}$ & $\begin{array}{l}0.76 \\
1.24\end{array}$ & $\begin{array}{l}0.21-1.94 \\
0.81-1.86\end{array}$ & $\begin{array}{r}9 \\
85\end{array}$ & $\begin{array}{l}0.57 \\
0.99\end{array}$ & $\begin{array}{l}0.26-1.09 \\
0.80-1.23\end{array}$ & $\begin{array}{l}1.30 \\
1.15\end{array}$ & $\begin{array}{l}0.40-4.23 \\
0.73-1.81\end{array}$ \\
\hline
\end{tabular}


positive breast cancers (11); this finding somewhat supports a causal association. Estrogen receptors have not been assessed in previous studies (8-10). A cohortbased case-referent assessment of fish intake, and other possible effect modifiers, as well as analyses of estrogen receptors in tumor tissues among the eastcoast women, will provide more data on this matter.

Dietary habits, like high salt intake and smoked food and a low intake of fresh fruits and vegetables, have been associated with a high incidence of stomach cancer (23). A significant increase in stomach cancer has previously been observed for Swedish eastcoast (but not westcoast) fishermen (4), as well as for Canadian (24) and British fishermen (25). The present results do not support an increased risk for stomach cancer in the eastcoast cohort. This discrepancy may be an indication that dietary habits differ between the eastcoast fishermen and their wives; for example, about a $60 \%$ higher intake of fresh fruits was observed among the women (22). Another possible interpretation is that a high intake of contaminated fatty fish from the Baltic Sea is not a risk factor for stomach cancer, even if this interpretation was somewhat hampered by the low expected number of stomach cancers in the present cohort.

The increased risk for squamous-cell cancer among the eastcoast fishermen (4) was not seen among their wives. Such a contradictory result was, however, not surprising. A combination of a dietary intake of TCDD, and other persistent organochlorine tumor promoters (26), and occupational exposure to initiating agents such as high doses of ultraviolet light through outdoor work, tars and oils, may be needed to cause a detectable increase in risk.

An excess mortality from multiple myelomas was seen among the eastcoast fishermen (4). Among women living in the Seveso area, where TCDD was accidentally released in 1976, an increased incidence of multiple myelomas has been observed (27). No increase in risk was seen in the eastcoast cohort, but a slight risk was indicated for the westcoast cohort. The low numbers of expected cases in the cohorts make firm conclusions impossible, however, at this stage.

The eastcoast fishermen had a significantly decreased incidence of colon cancer (4). It is known that colon cancer risk is decreased by dietary fibers and high physical activity (28) but increased by high levels of dietary fat and protein and a high total energy intake (29). No decreased incidence of colon cancer was seen among the eastcoast women, possibly because they had less physically demanding jobs than their husbands. On the other hand, no such gender difference in colon cancer risk was seen when the westcoast fishermen and their wives were compared. Whether the fish intake has been of any importance for these discrepancies remains unclear.
Among the eastcoast fishermen a decreased mortality in cardiovascular diseases was observed when comparisons were made with the general population (4). It has been hypothesized that this finding may be due to a high intake of fatty fish, rich in n-3 PUFA, but the lack of such a decreased risk among the wives of the eastcoast fishermen does not offer much support to this assumption.

\section{Acknowledgments}

This work was supported by grants from the Swedish Environmental Protection Agency, the Swedish Work Environment Fund, the Swedish Cancer Society, research funds at the Lund University Hospital, and at the Medical Faculty, Lund University.

The authors thank Ms M Wikman and Z Mikoczy, BSc, for their help with establishing the cohort, and U Strömberg, $\mathrm{PhD}$, for his assistance with the statistical analysis and for his fruitful discussions.

\section{References}

1. Asplund L, Svensson B-G, Nilsson A, Eriksson U, Jansson B, Jensen S, et al. Blood levels of different PCBs, DDT and DDE, and human fish consumption. Arch Environ Health 1994:49:477-86.

2. Svensson B-G, Nilsson A, Hansson M, Rappe C, Åkesson B, Skerfving S. Exposure to dioxins and dibenzofurans through the consumption of fish. N Engl J Med 1991;324:8-12.

3. Hagmar L, Lindén K, Nilsson A, Norrving B, Åkesson B, Schütz A, et al. Cancer incidence and mortality among Swedish Baltic Sea fishermen. Scand J Work Environ Health 1992; $18: 217-24$.

4. Svensson B-G, Mikoczy Z, Strömberg U, Hagmar L. Mortality and cancer incidence among Swedish fishermen with a high dietary intake of persistent organochlorine compounds. Scand J Work Environ Health 1995;21:106-15.

5. Kociba RJ, Keyes DG, Beyer JE, Carreon RM, Wade CE, Dittenber DA, et al, Results of a two year chronic toxicity and oncogenicity study of 2,3,7,8-tetrachlorodibenzo-p-dioxin in rats. Toxicol Appl Pharmacol 1978;46:279-303.

6. Brown DP. Mortality of workers exposed to polychlorinated biphenyls: an update. Arch Environ Health 1987;42:333-9.

7. Manz A, Berger J, Dwyer JH, Flesch-Janys D, Nagel S, Waltsgott $\mathrm{H}$. Cancer mortality among workers in chemical plant contaminated with dioxin. Lancet 1991;338:959-64.

8. Mussalo-Rauhamaa H, Häsänen E, Pyysalo H, Antervo K, Kauppila R, Pantzar P. Occurrence of beta-hexachlorocyclohexane in breast cancer patients. Cancer 1990;66:2124-8.

9. Falck F, Ricci A, Wolff MS, Godbold J, Deckers P. Pesticides and polychlorinated biphenyl residues in human breast lipids and their relation to breast cancer. Arch Environ Health 1992; 47:143-6

10. Wolff MS, Toniolo PG, Lee EW, Rivera M, Dubin N. Blood 
levels of organochlorine residues and risk of breast cancer. JNCI 1993;85:648-52.

11. Dewailly E, Dodin S, Verreault R, Ayotte P, Sauvé L, Morin $J$, et al. High organochlorine body burden in women with estrogen receptor-positive breast cancer. JNCI 1994;86:2324.

12. Unger M, Kior H, Blichert-Toft M, Olsen J, Clausen J. Organochlorine compounds in human breast fat from deceased with and without breast cancer and in a biopsy material from newly diagnosed patients undergoing breast surgery. Environ Res 1984;34:24 8.

13. Krieger N, Wolff MS, Hiatt RA, Rivera M, Vogelman J, Orentreich $\mathrm{N}$. Breast cancer and serum organochlorines: a prospective study among white, black, and Asian women. JNCI 1994;86:589—99.

14. Johnson DC, Sen M, Dey SK. Differential effects of dichlorodiphenyltrichloroethane analogs, chlordecone, and 2,3,7,8tetrachlorodibenzo- $p$-dioxin on the establishment of pregnancy in the hypophysectomized rat. Proc Sol Exp Biol Med 1992;199:42-8.

15. Korach KS, Sarver P, Chae K, McLachlan JA, McKinney JD. Estrogen receptor-binding activity of polychlorinated hydroxybiphenyls: conformationally restricted structural probes. Molecular Pharmacol 1987;33:120-6.

16. Kromhout D, Bosschieter EB, Lezenne Coulander C. The inverse relation between fish consumption and 20 -year mortality from coronary heart disease. $N$ Engl J Med 1985;312:1205-9.

17. Checkoway H, Pearce NE, Crawford-Brown DJ. Research methods in occupational epidemiology. Oxford: Oxford University Press, 1989

18. Breslow NE, Day NE. Statistical methods in cancer research; vol II (The design and analysis of cohort studies). Lyon: International Agency for Research on Cancer (IARC), 1987. IARC scientific publications, no 82.

19. Clayton D, Hills M. Statistical models in epidemiology. Ox- ford: Oxford University press, 1993.

20. Kelsey JL. Breast cancer epidemiology: summary and future directions. Epidemiol Rev 1993;15:256-63.

21. Rylander L, Strömberg U, Hagmar L. Decreased birthweight among infants born to women with a high dietary intake of fish contaminated with persistent organochlorine compounds. Scand J Work Environ Health 1995;21:368 - 75.

22. Svensson B-G, Nilsson A, Jonsson E, Schütz A, Åkesson B, Hagmar $L$. Fish consumption and exposure to persistent organochlorine compounds, mercury, selenium and methylamines in Swedish fishermen. Scand J Work Environ Health 1995;21:96-105.

23. Howson C P, Hiyama T, Wynder EL. The decline in gastric cancer: epidemiology of an unplanned triumph. Epidemiol Rev 1986;8:1-27.

24. Gallagher RP, Threlfall WJ, Band PR, Spinelli JJ. Cancer mortality experience of woodworkers, loggers, fishermen, farmers, and miners in British Columbia. Natl Cancer Inst Monogr 1985;69:163-7.

25. Schilling RSF. Hazards of deep-sea fishing. Br J Ind Med 1971;28:27-35.

26. Flodström S, Ahlborg UG. Relative liver tumor promoting activity of some polychlorinated dibenzo-p-dioxin-, dibenzofuran- and biphenyl-congeners in female rats. Chemosphere 1992;25:169-72.

27. Bertazzi PA, Pesatori AC, Consonni D, Tironi A, Landi MT, Zochetti $C$. Cancer incidence in a population accidentally exposed to 2,3,7,8-tetrachlorodibenzo-para-dioxin. Epidemiology 1993;4:398-406.

28. Gerhardsson M, Floderus B, Norell SE. Physical activity and colon cancer risk. Int J Epidemiol 1988;17:743-6.

29. Potter J D. Large bowel cancer: epidemiology and biology. Z Gastroenterol 1989;24:137-40.

Received for publication: 7 June 1995 